\title{
A Literature Review On Chief Executive Officer Hubris And Related Constructs: Is The Theory Of Chief Executive Officer Hubris An Antecedents Or Consequences?
}

Hyunjun Park, Incheon National University, South Korea

Youngtae Yoo, Incheon National University, South Korea

\begin{abstract}
This paper reviews the theory of Chief Executive Officer hubris and related constructs. It is to identify the area of Chief Executive Officer hubris clearly and to clarify the confusion of related constructs which includes: overconfidence, Chief Executive Officer celebrity, and narcissism. We examined the four related constructs comprehensively and evaluated Chief Executive Officer hubris construct as an antecedent or consequence. Throughout the research mainstream, these research related constructs often use the word hubris interchangeably. Many researchers are confused whether Chief Executive Officer hubris is an antecedent or consequence? We will attempt to resolve this issue by examining antecedents and consequences of Chief Executive Officer hubris and related constructs. Furthermore, suggestions and implications for future research based on Chief Executive Officer hubris will be assessed.
\end{abstract}

Keywords: CEO Hubris; Overconfidence; CEO Celebrity; Narcissism

\section{INTRODUCTION}

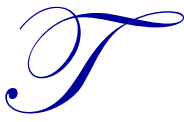

he Greek myths originated the term hubris, and the definition is defined as extreme self-confidence and pride (Hayward \& Hambrick, 1997). Roll (1986) brought hubris to attention to the business world. Manager infected by hubris over price their bids compare to the current company valuation. They simply pay too much for their targets during a takeover.

Historically, the characteristics of hubris can be seen by famous leaders such as Napoleon and Adolf Hitler. The case of Enron and WorldCom also exhibits a failure case with a leader who has characteristics of Chief Executive Officer (CEO) hubris. These examples mentioned, have been affected by hubris which drives leaders to be reckless and arrogant during their reign of leadership. By looking into hubris, we can explain and find out why these past successful leaders made their decisions which were bound to fail (Hayward, 2007).

In our research, the first related construct of CEO hubris is overconfidence. We have discovered that hubris originated from being overly confident, and a related theory refers to CEO with hubris as overconfidence which describes one's exaggerated belief that he or she can predict the direction of their future outcomes (Camerer \& Lovallo, 1999). A second related construct to CEO with a hubris is Chief Executive Officer (CEO) celebrity, which is about journalist creating a CEO through media praise which creates and change the CEO status extremely positively and their egotistical view of the world. There are many factors which add to the makings of CEO celebrity, and they are publicists, and public relations staff are the primary factors. Also, Hayward, Rindova, and Pollock (2004) stated that celebrity is created when CEOs constructive activities lead to the performance of a company to be highly positive.

The final related construct to CEO with a hubris is narcissism, and this is related to self-love. de Vries (1994) stated that for a person to survive daily, he or she must have self-esteem which is secured. However, someone who has a Copyright by author(s); $\underline{\text { CC-BY }}$ 
self-esteem which is unstable is bound to approach to the characteristics of having extreme self-love. This kind of characteristics of narcissism gives negative connotation of a person being psychopathological (de Vries, 1994). Narcissists who are reactive have a high sense of self-importance, and cares less about others. Furthermore, they have an illusion of excepting their problems to be unique and oppressive.

These related theories are all very similar and show consensus regarding the CEO characteristics of being extremely arrogant and not concerning about others. They use the words of overconfidence, pride, and proud interchangeably throughout their research. Therefore, this has caused much confusion to the researchers in these fields, whether the CEO hubris is an antecedent or consequence? This paper will attempt to resolve the confusion of these related constructs by looking into the definitions, causes, and consequences. Moreover, it will attempt to assess whether CEO hubris is an antecedent or consequence. Furthermore, we will give suggestions and research implications for future researchers who are interested in the field of CEO hubris. We have organized this paper into nine different parts, and they are: 1) introduction, 2) CEO hubris phenomenon, 3) overview of the model, 4) overconfidence phenomenon, 5) CEO celebrity phenomenon, 6) narcissism phenomenon, 7) discussion 8) limitation and future research and 9) conclusion.

\section{CEO HUBRIS: THE PHENOMENON}

\subsection{CEO Hubris Definition}

The definition of hubris hypothesis was brought from Roll (1986). The hubris hypothesis exemplified that an individual decision-making is made from the current market valuation and loss in value of the bidding shares. Some of the gains can exist for some corporate. However, the average takeover premium could still be caused by valuation error and possibly hubris. Therefore, scholars still do not fully comprehend the motives behind mergers and gentle offers. The central expectation of the total outcome during a takeover with CEO with hubris is negative. The pattern is usually consistent regarding hubris hypothesis and often, predicts the loss of value of bidding firm's shares. Hubris hypothesis can imply inefficiency in the market for corporate control.

Haspeslagh and Jamison (1991) stated that the egos from the acquiring managers outpace their logic frequently. Possible explanations of this kind of behavior are related to positive profiles of their individual background during a takeover pricing (Hambrick \& Mason, 1984). Also, Hayward and Hambrick (1997) stated that CEO with hubris is an individual level construct on CEO trait (exaggerated pride or self-confidence). Furthermore, CEO with hubris feeds on further success. Also, they have a countless history of not following the rules of the game and inflicting sacrifice to others and most importantly getting away with it.

A new conceptual approach called hyper core self-evaluation was introduced. Hiller and Hambrick (2005) stated that a CEO with extreme core self-evaluation carries high self-confidence. Furthermore, Lin, Michayluk, Oppenheimer, and Reid (2008) focused their studies on the Japanese market and examined the mergers and acquisition activities and have found that hubris are also shown internationally. It argues that hubris can be affected by better performance in profit or past stock return regarding their managerial skills. 
Table 1. Key Studies of CEO hubris

\begin{tabular}{|c|c|c|c|}
\hline Study & Definition & Cause & Consequence \\
\hline Roll (1986) & $\begin{array}{l}\text { - Decision makers pay too } \\
\text { much for their acquiring } \\
\text { target }\end{array}$ & $\begin{array}{l}\text { - Few takeover offers during } \\
\text { his/her career. } \\
\text { - Convince himself that the } \\
\text { valuation is right }\end{array}$ & - M\&A premium \\
\hline $\begin{array}{l}\text { Hayward \& Hambrick } \\
\text { (1997) }\end{array}$ & $\begin{array}{l}\text { Individual level constructs } \\
\text { on CEO trait (exaggerated } \\
\text { pride or self-confidence). }\end{array}$ & $\begin{array}{l}\text { - Recent performance } \\
\text { - Media praise } \\
\text { - Self-Importance }\end{array}$ & - M\&A premium \\
\hline Raj \& Forsyth (2003) & $\begin{array}{l}\text { - Confidence in its ability } \\
\text { and adding personal gain } \\
\text { believing 'no lose' situation } \\
\text { exists. } \\
\text { - Striving to increase their } \\
\text { standing and market power }\end{array}$ & - Past success & $\begin{array}{l}\text { - Leads to degree of } \\
\text { arrogance } \\
\text { - Pays large premium during } \\
\text { acquisition }\end{array}$ \\
\hline $\begin{array}{l}\text { Hiller \& Hambrick } \\
(2005)\end{array}$ & $\begin{array}{l}\text { - Self-confidence } \\
\text { - Self-worth } \\
\text { - Self-potency } \\
\text { - Freedom from anxiety }\end{array}$ & $\begin{array}{l}\text { Emotional stability, } \\
\text { Generalized self-efficacy, } \\
\text { Locus of control, and Self- } \\
\text { esteem } \\
\text { - Hyper CSE executives are } \\
\text { sure they will prevail }\end{array}$ & $\begin{array}{l}\text { - Take grandiose actions } \\
\text { - Catastrophic results }\end{array}$ \\
\hline $\begin{array}{l}\text { Lin, Oppenheimer, } \\
\text { Michayluk, \& Reid } \\
\text { (2008) }\end{array}$ & $\begin{array}{l}\text { - Irrational managers \& } \\
\text { investors }\end{array}$ & - Past excess market returns & - Value destroying M\&A \\
\hline Li \& Tang (2010) & $\begin{array}{l}\text { - Psychological bias of } \\
\text { overconfidence }\end{array}$ & - Media Praise & $\begin{array}{l}\text { Overestimate the likelihood } \\
\text { of success of strategic } \\
\text { initiative and takes risk }\end{array}$ \\
\hline
\end{tabular}

This above discussion can be summarized by the following propositions:

Proposition 1: CEO with a hubris are more likely to make decisions to their self-seeking interest.

\subsection{Hubris Cause and Consequence}

The critical issue of CEO hubris research lacks measurement of CEO with hubris. However, Hayward and Hambrick (1997) first empirically examine this phenomenon using the factors of organization with recent success, media acclaim, and CEOs importance regarding salary. When these kinds of factors exist for a CEO, it may cause major negative effects on firms outcomes. Later, Seth, Song, and Pettit (2000) argued that the firms are over-valued during valuation by managers who are bidding. This kind of irrational behavior is shown through CEO with hubris. Also, Raj and Forsyth (2003) discovered that past success might lead to the feeling of supremacy which will result in overestimation of their target firm during the takeover.

The concept of hyper core self-evaluation has given researcher to look and evaluate executive to another dimension of analysis. An executive who has hyper core self-evaluation have characteristics of big scale actions which ultimately cause devastating consequences. Hiller and Hambrick (2005) states that hyper core self-evaluated executive can be considered hubris. The theory portrays four factors: emotional stability, locus of control, self-esteem, and self-efficacy. The emotional stability deals with levels of anxiety. The locus of control refers to belief which a person can control the events of their life (Rotter, 1954). Harter (1990) described the factor of self-esteem as an individual who has a positive personality, and accepts oneself. Lastly, self-efficacy deals with a person who believes that their competence characteristics can positively accomplish anything (Gist \& Mitchell, 1992). In a broader perspective, hubris can be shown internationally. Lin, Michayluk, Oppenheimer, and Reid (2008) argued that Japanese bidders are affected by hubris through good performance in profitability, and prior stock performance engages in value-destroying mergers and acquisition. 
Furthermore, Li and Tang (2010) researched on CEO with hubris which takes risk-taking behaviors to examine the relationship using the moderating variable of managerial discretion. The CEO with hubris was measured using the media acclaim from Chinese business media and survey results of CEOs were used from the prior firm performance. The managerial discretion was used for the moderating variable for this research. It was measured using specific environmental and organizational factors. The result showed high positive correlation between CEO with hubris and company which demonstrate bold risk when the managerial discretion was stronger. Thus, the figure 1 model present CEO hubris as an antecedent. It shows the CEO with hubris will make the decision towards extreme risk because of their arrogant characteristics

This above discussion can be summarized by the following propositions:

Proposition 2: CEO with hubris can be an antecedent when CEO hubris are more likely to make a decision to their self-interest which is bold because of its arrogant characteristics.

Figure 1. Model of CEO Hubris as an Antecedents

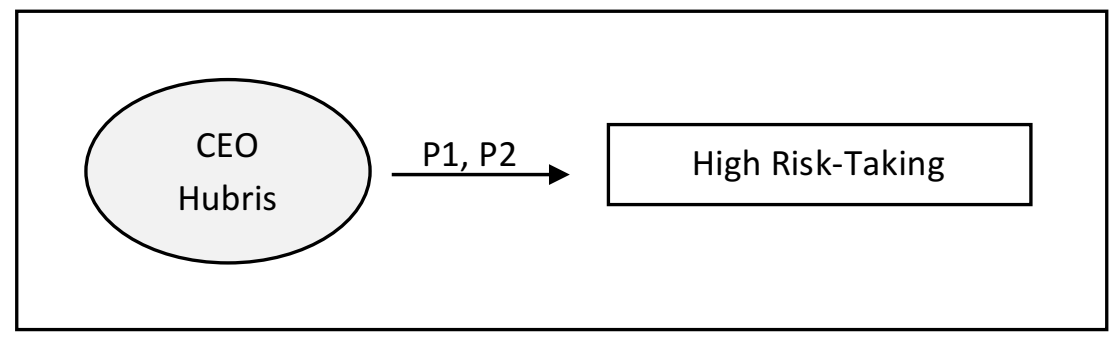

\section{OVERVIEW OF THE MODEL}

To examine the issues mentioned above regarding CEO with hubris, we are presenting a summary model in Figure 2. This model exhibits that when CEO hubris are applied as a consequence, then the three related constructs are considered as antecedents. It shows that overconfidence, CEO celebrity, and narcissism are all factors which will create CEO with hubris. When CEO hubris is applied as an antecedent, then the high-risk taking behavior of selfinterest will be shown as a consequence. Each of the three related constructs has rationales for explaining the antecedent of CEO hubris and negative results in performances which we have evaluated in this research.

Figure 2. Summary Model of CEO Hubris as an Antecedents and Consequences

CEO Hubris as Consequence CEO Hubris as Antecedent

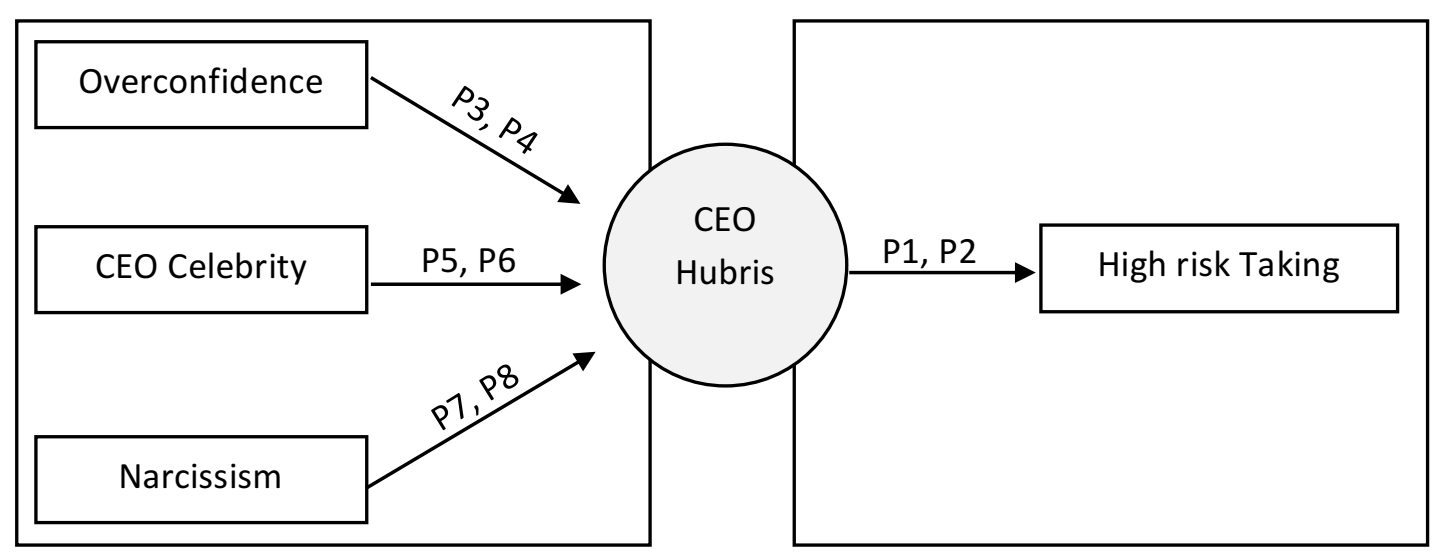

Copyright by author(s); $\underline{\mathrm{CC}-\mathrm{BY}}$ 


\section{OVERCONFIDENCE: THE PHENOMENON}

\subsection{Overconfidence Definition}

It has been understood that studies from experimental economics and social psychology have found that people exhibit overconfidence in their judgment. The first discovery of overconfidence is from Alpert and Raiffa (1982). However, Russo and Schoemaker gave the most influence on the study of overconfidence. The study revealed that rational managers are also prone to overconfidence. Also, an overconfident CEO can be described as CEO with hubris, and the characteristics of such can be - arrogant, conceit, egotism, greed, and shameless. These magical thinkers have become to a belief that their decision towards any possible situation in business practices are precise and leads to a successful consequence.

Scholars in this field described that most people have a tendency of belief that they are objectively much better than other people compare to their actual current status (Regan, Gosselink, Hubsch, \& Ulsh, 1975). Also, Fischoff and Beyth (1975) discovered that a person has the power to foretell the future is much more valuable than a person who demonstrates. In addition, Blascovich, Ginsburg, and Howe (1975) investigated gamblers and discovered that they overvalued their estimation of success during their games. Furthermore, Meadows, Meadows, Randers, and Behrens, (1972) stated a person whose success was based on their capabilities have great impacts during the process of future planning. An overconfident manager strongly believes that they are much better than typical managers. They have strong conviction that they will perform outstandingly in a market due to their repeated success of their sales volume. Therefore, high-risk decision making can frequently be involvedfrequently.

As overconfidence study expanded, other scholars researched the theory more in depth. DeBondt and Thaler (1995) stated the theory of overconfidence as pioneering and ground-breaking for the area of psychology. Many researchers in this area define overconfidence as someone who can predict the outcome of anticipated future (Camerer \& Lovallo, 1999). Also, Russo and Schoemaker (1992) stated that overconfidence describes the precise overvalue of positive future outcome. The research on overconfidence concentrates and bases their papers on individuals' justification for bias. An overconfident person behaves and believes that he or she is abnormally successful. Also, a person who is over confident has a belief that they consume much more accurate knowledge even about an event which has not occurred, which can be looked upon as risk perception bias. Managers who are overconfident have this belief that they can modify the risk of projects and that they are in control in which Brown and Sarma (2007) describes this kind of state of managers' as "illusion of control."

There are other explanations of overconfidence. Barber and Odean (1999) stated that an investor who is over confident overvalues their understanding of the financial security. Therefore, overconfident investors think more towards their valuations rather than others. Also, An overconfident investor's trade extremely much more depending on a gender (Barber \& Odean, 2001). The study argued that males are considerably more overoptimistic than females. Therefore, males will trade excessively much more than their opposite sex.

Simon and Houghton (2003) discovered that managers who are overconfident make arrogant decisions when there is a product pioneering. An overconfidence occurs greatly in pioneering decision contexts compare to incremental decision contexts. Also, overconfidence encourages managers to pursue a riskier action. Moreover, a manager who is overconfident stems from the theory of self-attribution bias which describes their success based on their capability which eventually creates a manager who is arrogant and eventually involves in various mergers and acquisition dealings (Doukas \& Petmezas, 2007). Furthermore, Hayward, Shepherd, and Griffin (2006) use the word hubris in the area of entrepreneurship which describes a founder to be overconfident by overestimating their future wealth through what they will generate from the venture. Lastly, Malmendier, Tate, and Yan (2007) researched the connection between manager who is overconfident and decision-related towards corporate financing. When a CEO hold their stock options beyond their threshold was considered as overconfident. 
Table 2. Key Studies of Overconfidence

\begin{tabular}{|c|c|c|c|}
\hline Study & Definition & Cause & Consequence \\
\hline Griffin \& Tversky (1992) & $\begin{array}{l}\text { - Often wrong but rarely in } \\
\text { doubt }\end{array}$ & $\begin{array}{l}\text { - Strength (strength or } \\
\text { extremeness of evidence) is } \\
\text { high, weight (weight or } \\
\text { credence) is low } \\
\text { - Ex. Letter of } \\
\text { recommendation }\end{array}$ & - Illusion of validity \\
\hline $\begin{array}{l}\text { Russo \& Schoemaker } \\
\text { (1992) }\end{array}$ & $\begin{array}{l}\text { - Strong belief about their } \\
\text { judgments }\end{array}$ & $\begin{array}{l}\text { - Availability bias } \\
\text { - Anchoring bias } \\
\text { - Confirmation bias } \\
\text { - Hindsight bias }\end{array}$ & $\begin{array}{l}\text { - Flaw in managerial } \\
\text { decision-making }\end{array}$ \\
\hline Camerer \& Lovallo (1999) & $\begin{array}{l}\text { - Neglecting the increased } \\
\text { level of competition }\end{array}$ & - Optimistic biases & $\begin{array}{l}\text { - Entry into competitive } \\
\text { games or markets \& fail }\end{array}$ \\
\hline Simon \& Houghton (2003) & $\begin{array}{l}\text { - Excessive certainty about } \\
\text { one's prediction }\end{array}$ & $\begin{array}{l}\text { - Pioneering product } \\
\text { - Extreme certainty } \\
\text { - Achieving success }\end{array}$ & - Product success failure \\
\hline Malmendier \& Tate (2005) & $\begin{array}{l}\text { Better than average: } \\
\text { When individuals assess } \\
\text { their relative skill, they } \\
\text { tend to overestimate their } \\
\text { acumen relative to } \\
\text { average }\end{array}$ & $\begin{array}{l}\text { - Holder } 67 \\
\text { - Longholder } \\
\text { - Net Buyer }\end{array}$ & $\begin{array}{l}\text { - The sensitivity of } \\
\text { investment to cash flow }\end{array}$ \\
\hline $\begin{array}{l}\text { Hayward, Shepherd, Griffin } \\
(2006)\end{array}$ & - Greater overconfident & $\begin{array}{l}\text { - Overconfidence in } \\
\text { knowledge, prediction, and } \\
\text { personal abilities }\end{array}$ & - Venture failure \\
\hline Brown \& Sarma (2007) & $\begin{array}{l}\text { - The "illusion of control" } \\
\text { over its consequence }\end{array}$ & $\begin{array}{l}\text { - Media coverage } \\
\text { - CEO dominance }\end{array}$ & $\begin{array}{l}\text { - Decision to undertake } \\
\text { acquisition }\end{array}$ \\
\hline Doukas \& Petmezas (2007) & $\begin{array}{l}\text { Belief that future merger } \\
\text { consequences are under } \\
\text { their control }\end{array}$ & - Self-attribution bias & $\begin{array}{l}\text { - Superior abnormal } \\
\text { returns }\end{array}$ \\
\hline $\begin{array}{l}\text { David, Graham, \& Harvey } \\
\text { (2007) }\end{array}$ & $\begin{array}{l}\text { - Overestimate the } \\
\text { forecasts or } \\
\text { underestimate the } \\
\text { variance of risk }\end{array}$ & $\begin{array}{l}\text { - Past own firm returns } \\
\text { - Age }\end{array}$ & $\begin{array}{l}\text { - High corporate } \\
\text { investment }\end{array}$ \\
\hline
\end{tabular}

The above discussion can be summarized by the following proposition:

Proposition 3: CEOs who are overconfident are more likely to overestimate their knowledge and be in a state of illusion of control.

\subsection{Overconfidence Cause and Consequence}

Russo and Schoemaker (1992) stated that causes of cognitive overconfidence are based on availability, anchoring, confirmation bias, and hindsight. The first factor of availability is to consider the fact that people were unable to predict their future critical directions. Second, anchoring is dealing with anchoring on one value or idea and does not adjust sufficiently. Third, confirmation bias deals with cognitive reason in dealings with predictions or forecasts based on one perspective; it is focused on the initial view rather than looking for other realistic evidence to support their judgments.

Griffin and Tversky (1992) suggested that people over-weight the strength of evidence by using the letter of recommendation (warmth of a letter, or the size of an effect) about the credibility of that type of evidence. Overconfidence is likely to occur when the strength of proof is high, and source credibility is low. Also, CEO who is overconfident promotes riskier acquisition by the illusion of control over its outcomes (Brown \& Sarma, 2007). Lastly, 
hindsight deals with believing that the world is more predictable than it is. These cognitive factors can have substantial impact on overconfident decisions during business practices.

Malmendier and Tate (2008a) stated that a CEO who is overoptimistic overvalues their capability and give negative outcomes on takeover targets. This overconfidence can be effected with companies who has sufficient cash and untapped debt capacity. A CEO was considered overconfident when it used longholder. This measurement deals with high levels of equity ownership. There was substantial evidence that overconfident CEO perform negatively during a takeover.

Malmendier and Tate (2005) argued that corporate investment distortions are based on managerial overconfidence. Also, overconfident CEO overinvest when there are sufficient funds internally. However, they shorten their investments when they have to find financing outside of their company. Overconfidence was measured through stock and options which CEO receive from compensation. The CEO cannot hedge the risk by short sell or trade. This phenomenon of under-diversification should make CEO to exercise their options early. However, the factors of holder 67 , longholder, and net buyer show opposite approach by overconfident CEO. The holder 67 describes $67 \%$ of money during the threshold of the fifth year. Some portion of the option should have been exercised, when an option is more than $67 \%$. The longholder factor deals with the expiration date rather than the vesting period of an option package. Lastly, net buyer deals with CEO buying additional stock in spite of the high exposure of company being at risk. If a CEO is overconfident, these three factors mentioned will be considered.

Malmendier \& Tate (2005) also develops a measurement for overconfidence by outside perception through how the media portrays the CEO by looking into the number of articles with words containing: confident and optimistic. Also, Lin et al. (2008) investigated that Japanese mergers and acquisitions market had characteristics of hubris presence. It used past market returns to measure the hubris affect. The results showed that overconfident managers were affected by hubris hypothesis which engaged in decision making which would make value-destroying mergers and acquisitions.

Hayward et al. (2004) stated that overconfidence arises when high level of accuracy occurs during an ex-ante event which surpasses ex-post precision. The feeling of being overconfident creates people to behave in ways in which they were not capable during normal state (Taylor \& Brown, 1988). Also, strategic actors such as negotiators and senior managers have been found to be overconfident in their judgments (Neale \& Bazerman, 1983; Hayward et al. 1997). Furthermore, a direct measure of overconfidence and overoptimism through a survey was utilized. They used short questionnaire and asked about 2,000 to 3,000 chief financial officers (CFO) to find out about the degree of miscalibration of CFO judgment in their investment. The term miscalibration is a behavioral bias which is similar to overconfidence (Ben-David, Graham, \& Harvey, 2007).

The theory of CEO with hubris based on entrepreneurship which involved overconfident founders was examined (Hayward, Shepherd, \& Griffin, 2006). The processes of being over confident deals with three psychological processes which are knowledge, prediction, and personal abilities. The environment of uncertainty in information, scarce feedback, and rare in positive results can make the founders operate with overconfidence and together it can link to characteristics of hubris. Thus, overconfident CEO with hubris can jeopardize the survival of their ventures.

The above discussion can be summarized by the following proposition:

Proposition 4: CEOs with overconfidence can be an antecedent of CEO hubris because being overconfident may lead to oneself to become arrogant which may eventually lead to high-risk decisions to their self-seeking interest.

\section{CEO CELEBRITY: THE PHENOMENON}

\subsection{CEO Celebrity Definition}

Leadership images are vital in a business world, and media can play a crucial role in constructing a leadership image. Past research towards mass communication has shown that press can influence people's cognition of changing one's 
initial beliefs (Katz, 1980). Chen and Meindl (1991) researched about how the press constructs a leader's image. Also, when a leader has a popular image, it is more likely to maintain that positive image through the mass media. Usually, business leaders are covered by journalists in the modern press. As more coverages are shown to the public, it can create Chief Executive Officer (CEO) celebrity.

The overall evaluation of a firm in a press can change their image (Deephouse, 2000). The sources for media reputation can come from company's press release, stakeholders, and media workers. Thus, media reputation can be considered as a resource, and it can also influence the performance of a firm. Also, media provided legitimacy which can affect and influence investor behavior (Pollock \& Rindova, 2003).

The term CEO celebrity is defined as journalist broadcast firm's positive consequence from CEO actions (Hayward et al. 2004). Also, the definition of celebrity can be based on three components: print and electronic mass media, attribution, and firm actions. Journalist selects the company for a coverage and delivers the information to massive audiences. The attribution deals with positive or negative consequences. A good example is that if there is a positive consequence, then the actor has caused the consequence, and this relationship can also be seen in the negative consequence. Lastly, the features of CEO's personality, characteristics, and choices can affect firm's actions and performances.

Everybody wants to be famous, and it applies to CEOs in the business world. However, CEOs who are a celebrity can have burdens. The burden factor of a celebrity leader is when receiving greater reward and this especially pertains to CEOs whose performance are high (Wade, Porac, Pollock, \& Graffin, 2006). This burden arises because the need to constantly over perform. Thus, certified CEOs received lower pay when company's performance was poor. A certified CEOs does seem to generate higher returns initially when they were first declared, but as the period grows longer the power of certified CEOs become lower.

Graffin, Wade, Porac, and McNamee (2008) discovered CEO status which can be measured through an annual contest of Financial World's CEO. A CEO can receive a gold, silver, and bronze medal for this award. Furthermore, a CEO who is a celebrity can use their high status to leverage and to make their subordinates into the future CEO position. The reason behind for this is because directors can rely on celebrity CEOs judgments and since the subordinates have learned under the $\mathrm{CEO}$ celebrity, their potentials are positively assumed.

Table 3. Key Studies of CEO Celebrity

\begin{tabular}{|c|c|c|c|}
\hline Study & Definition & Cause & Consequence \\
\hline $\begin{array}{l}\text { Hayward, Rindova, \& } \\
\text { Pollock (2004) }\end{array}$ & $\begin{array}{l}\text { When journalist } \\
\text { broadcast the attribution } \\
\text { of firm's positive } \\
\text { performance due to } \\
\text { CEO's actions }\end{array}$ & $\begin{array}{l}\text { - Distinctive \& consistent } \\
\text { action from CEO than } \\
\text { industry norm } \\
\text { - Journalists bias }\end{array}$ & $\begin{array}{l}\text { - Journalists exaggerate } \\
\text { CEO's contribution to } \\
\text { firm performance }\end{array}$ \\
\hline $\begin{array}{l}\text { Wade, Porac, Pollock, \& } \\
\text { Graffin (2006) }\end{array}$ & $\begin{array}{l}\text { - Publicly identified as a } \\
\text { star carries "burden of } \\
\text { celebrity." }\end{array}$ & - Certification contest & $\begin{array}{l}\text { - Positively and negatively } \\
\text { affect future performance } \\
\text { \& CEO compensation }\end{array}$ \\
\hline $\begin{array}{l}\text { Graffin, Wade, Porac, \& } \\
\text { McNamee (2008) }\end{array}$ & $\begin{array}{l}\text { - CEO with greater or } \\
\text { lesser status by the press } \\
\text { influences executive pay } \\
\text { and promotion }\end{array}$ & - CEO status & $\begin{array}{l}\text { Positive \& negative } \\
\text { effect on CEO } \\
\text { compensation and top } \\
\text { management team }\end{array}$ \\
\hline Malmendier \& Tate (2009) & $\begin{array}{l}\text { - Highly skewed of } \\
\text { income, market share \& } \\
\text { public attention }\end{array}$ & - CEO characteristics & $\begin{array}{l}\text { - Award winning CEO's } \\
\text { underperform in } \\
\text { performance }\end{array}$ \\
\hline
\end{tabular}

The above discussion can be summarized by the following propositions:

Proposition 5: CEO Celebrity is more likely to be created when more mass media coverages are shown to the public and more likely to get a higher salary. 


\subsection{CEO Celebrity Cause and Consequence}

A journalist plays a critical role in creating and informing the public about the firm and the CEO (Baum \& Powell, 1995). Journalists have the ability to create behaviors of managers indirectly (Clapham \& Schwenk, 1991). Moreover, journalists create CEO celebrity during the process of ascribing firm's performance (Hayward et al. 2004). There are other contributors in creating CEO celebrity, and they are - publicists, analysts, and public relations staff.

When a company has a CEO celebrity, it can be valuable to the firm. Formbrun (1996) investigated that highly recognized CEO encourage stakeholders that company's futures are positive. It also can attract high-quality employees, leveraging suppliers, and have access to better-needed capital for the company. However, CEO celebrity can lead to harmful outcomes for a company by making managers be overconfident and lead to characteristics of hubris which can destroy the future performance of the company (Wade et al. 2006). Lastly, Fombrun (1996) discovered that publicly announced CEOs have the burden of being a celebrity, which implies that CEO who is a celebrity is highly responsible when there is an adverse consequence and when the expectations are not met.

The theory of self-attribution is being used to approach for the cause of CEO celebrity. Managers blame failures for the external reason and internalize for success. Another cause of CEO celebrity is business press (Chen \& Meindl, 1991). Furthermore, the creditability of being CEO who is a celebrity may increase prestige power by enhancing their status among stakeholders (Dalton, Barnes, \& Zalenznik, 1968). Also, Hayward et al. (2004) observed and discovered that CEOs who are famous and who are primary stakeholders supports and do not discard the status of a CEO who are a celebrity. Furthermore, their perspective of $\mathrm{CEO}$ who is a celebrity is considered as intangible asset for the company.

This intangible asset can be diffused by the press and influence the relationships between the CEO and shareholders. Graffin et al. (2008) stated CEO status through certification competition could be endorsed by the business press to create positive $\mathrm{CEO}$ status. Therefore, $\mathrm{CEO}$ with a high status received higher average compensation compared to low status (Malmendier and Tate, 2008b). A CEO celebrity, also known as the CEO star brings a burden of celebrity, which describes that based on the firm performance, star CEO is either praised or blamed. Also, the CEO compensation fluctuates depending on the company performance. If a company's performance is positive, a star CEO compensation will be much higher than a $\mathrm{CEO}$ who is not considered a star. To meet the positive performance expectations, normally star CEOs have to make riskier choices by making riskier investments for higher returns. Therefore, these kinds of public endorsements can increase the bargaining power of celebrity to act and behave in a dangerous and arrogant manner.

The above discussion can be summarized by the following propositions:

Proposition 6: CEO Celebrity can be an antecedent of CEO hubris because journalist plays a significant role in creating a positive image of $\mathrm{CEO}$ to become a $\mathrm{CEO}$ celebrity to be a valuable intangible asset which may eventually lead to high-risk decisions to their self-seeking interest of fame and power.

\section{NARCISSISM: THE PHENOMENON}

\subsection{Narcissism Definition}

The past research on narcissism has an extensive and rich history. Narcissism was first introduced in psychology by Havelock Ellis in 1898 to describe people absorbed in self-admiration. Freud discovered behavioral traits of narcissists and acknowledged that narcissism is a state in which individuals wish to act purely out of a desire to strive for an ideal self (Freud, 2014). Throughout the research stream of narcissism, researchers have thought of narcissism with various descriptions such as a clinical disorder (Kernberg, 1975), social or cultural trend (Lasch, 1991), and, as a psychological construct (Raskin \& Terry, 1988). Thus, Psychology scholars have developed the validity and reliability tests over the years. The Narcissistic Personality Inventory (NPI) which is a personality test which is mostly used in this field. Also, the personal trait on individual differences in narcissism was measured using NPI (Rasking \& Hall, 1979). In addition, there are several indicators of narcissism. First, leadership/authority; Second, power/conceit; Third, selfabsorption/self-love. Lastly, showing off/status (Emmons, 1984). 
Narcissists have confidence in that they are better than other people and self-assured of their capabilities and skills. Also, they perceive themselves better than the average person on many different qualities and characteristics such as -intelligence, extraversion, and openness to experience (Campbell, Rudich, \& Sedikides, 2002). Moreover, Judge, LePine, and Rich (2006) discovered that narcissists rate themselves very highly on leadership qualities and contextual performance. Furthermore, narcissists are likely to have a strong self-enhancement bias in self-evaluations of performance (John \& Robins, 1994). More importantly, Kroll, Toombs, and Wright (2000) argue that the cause of CEO with hubris arise from narcissism.

Although narcissists believe in self-admiration, they also need external reinforcement or 'narcissistic supply' (Kernberg, 1975). Narcissism by definition has a strong social component. Narcissists need people who will praise them through applause and cheer. Furthermore, their performance escalates during a crisis or when people are watching (Wallace \& Baumeister, 2002). Lastly, Narcissists regularly engage in social comparison (Bogart, Benotsch, \& Pavlovic, 2004), and pursue constant external self-affirmation (Morf \& Rhodewalt, 2001).

Most of successful CEOs have narcissism which drives and reinforce the characteristics of narcissism. Hiller \& Hambrick (2005) described narcissism as self-love. Also, to survive in real life, secured self-esteem is required by CEOs. However, when it is not present, excessive self-love is attempted (de Vries, 1994). Also, Lubit (2002) stated that narcissism with pathological form has characteristics of: grandiose senses of arrogance, taking advantage of others or diminishing them, addiction towards compliments and lastly lack empathy. Moreover, narcissism portrays grandiose characteristics through self-enhancing, vindictive, and exploitative while interpersonal stress is nonsignificant (Dickinson \& Pincus, 2003; Duchon \& Drake, 2009; Aktas, Bodt, Bollaert \& Roll, 2012.

A vast volume of research based on narcissism in executives has been written. However, much of the research have been theoretical rather than empirical (de Vries, 1994; de Vries and Miller, 1985). Campbell, Reeder, Sedikides, and Elliot (2000) researched that there are different types of a narcissist in the areas of psychological functions, and they are: egocentrism, and sense of uniqueness. Also, narcissist strategically regulates through self-concept which includes arrogance, imaginations of being famous, power, and adverse reaction to possible threats. Lastly, narcissists have poor interpersonal relationships with others which can be shown through misuse of others and personal power.

All the leaders can have a certain sense of narcissism internally. They have the notion of self-love, self-importance, self-confidence, great egocentricity, and fantasies of power. Also, Raskin and Terry (1988) discovered factors of a person with a personality of narcissism and they are - power, showing off, superiority, privilege, and vanity. In addition, Deluga (1997) examined on efficient and decisive leadership based on American Presidents using historiometric procedures to evaluate the research. Historiometry use quantitative measurement which includes content analysis to examine biographical information of historical figures. To find narcissism using historical data, it used NPI to evaluate the presidential narcissism.

Raskin and Shaw (1988) explored a study between narcissism and use of personal pronouns during monologs. The subjects of twenty-four males and twenty-four females were asked to talk about any topic for five minutes. The subjects then were tested using the NPI, Eysenck personality questionnaire, and internal-external locus of control. The results showed that individuals that used more of the first person singular pronouns "I" then "We" scored high as narcissism. Also, Sanford (1942) viewed the usage of the pronoun as indicators of egocentrism. Furthermore, egocentric people are more likely to use "I."

Campbell, Goodie, and Foster (2004) discovered narcissism leads to overconfident and negative decision-making. There were three studies for this research. The first study was about narcissism predicted overconfidence. The second study was about gambling. A person with a narcissistic character showed more willingness to gamble. Lastly, narcissist's forecasts upcoming performance which was only grounded on performance outlooks.

Young and Pinsky (2006) were the first researchers to obtain personality characteristics data of famous celebrities. The results showed that stars have extreme characteristics of narcissism. Also, celebrities who are females revealed significantly higher in narcissism because of the characteristics of showing off and vanity. 
Table 4. Key Studies of Narcissism

\begin{tabular}{|c|c|c|c|}
\hline Study & Definition & Cause & Consequence \\
\hline $\begin{array}{l}\text { Raskin \& Shaw } \\
(1988)\end{array}$ & $\begin{array}{l}\text { - Extreme self-centeredness } \\
\text { - Self-absorption } \\
\text { - Self-importance } \\
\text { - Fantasies of unrealistic goals } \\
\text { - Constant attention \& } \\
\text { admiration }\end{array}$ & - Personality & $\begin{array}{l}\text { - Select personal topics } \\
\text { (past experience or belief) } \\
\text { than impersonal topics } \\
\text { - Verbal behavior (Pronoun } \\
\text { usage "I" than "We" }\end{array}$ \\
\hline Deluga (1997) & $\begin{array}{l}\text { - Self-indulgence } \\
\text { - Abuse of leader power } \\
\text { - Need for power }\end{array}$ & - Charismatic leadership & $\begin{array}{l}\text { - Impact of presidential } \\
\text { performance }\end{array}$ \\
\hline $\begin{array}{l}\text { Campbell, Reeder, } \\
\text { Sedikides \& Elliot } \\
(2000)\end{array}$ & $\begin{array}{l}\text { - Self-Concept } \\
\text { - Egocentrism } \\
\text { - Self-importance } \\
\text { - Personal entitlement } \\
\text { - Exploitation of partner }\end{array}$ & $\begin{array}{l}\text { - Self-serving bias } \\
\text { - Rating of task importance }\end{array}$ & $\begin{array}{l}\text { - Self-enhancement } \\
\text { strategy }\end{array}$ \\
\hline $\begin{array}{l}\text { Kroll, Toombs, \& } \\
\text { Wright }(2000)\end{array}$ & $\begin{array}{l}\text { - Arrogant confidence } \\
\text { - Does not play the same rule } \\
\text { like everyone else }\end{array}$ & $\begin{array}{l}\text { - Narcissism } \\
\text { - Series of success } \\
\text { - Uncritical acceptance of } \\
\text { accolades } \\
\text { - Exemption from the rules }\end{array}$ & $\begin{array}{l}\text { - Confidence turns to } \\
\text { arrogance } \\
\text { - Reliance on simplistic } \\
\text { formula for success } \\
\text { - Failure to face changing } \\
\text { realities }\end{array}$ \\
\hline Lubit (2002) & $\begin{array}{l}\text { - Self-love } \\
\text { - Grandiosity } \\
\text { - Entitlement to exploit others } \\
\text { - Devaluation of others }\end{array}$ & $\begin{array}{l}\text { - Effects of early childhood } \\
\text { experience, psychological } \\
\text { conflicts \& defense } \\
\text { mechanism, fragile self- } \\
\text { esteem } \\
\text { - - Behavior learned by others }\end{array}$ & - Destructive narcissists \\
\hline $\begin{array}{l}\text { Dickinson \& Pincus } \\
\text { (2003) }\end{array}$ & $\begin{array}{l}\text { - Anti-social } \\
\text { - Domineering } \\
\text { - Vindictive }\end{array}$ & - Grandiose character & $\begin{array}{l}\text { - Unrealistic view of } \\
\text { themselves to others }\end{array}$ \\
\hline $\begin{array}{l}\text { Campbell, Goodie, \& } \\
\text { Foster (2004) }\end{array}$ & - Feel they are superior to others & - Overconfidence & $\begin{array}{l}\text { - Deficit in decision- } \\
\text { making }\end{array}$ \\
\hline $\begin{array}{l}\text { Young \& Pinsky } \\
(2006)\end{array}$ & $\begin{array}{l}\text { - Exhibitionism } \\
\text { - Superiority } \\
\text { - Vanity }\end{array}$ & - Celebrities & $\begin{array}{l}\text { - High degree of } \\
\text { narcissism }\end{array}$ \\
\hline $\begin{array}{l}\text { Chatterjee \& } \\
\text { Hambrick (2007) }\end{array}$ & $\begin{array}{l}\text { - Generates more extreme } \\
\text { performance } \\
\text { - (Big wins or Big losses). }\end{array}$ & - Leadership personality & $\begin{array}{l}\text { - Strategic dynamism } \\
\text { - Acquisitions } \\
\text { - Performance extremeness } \\
\text { - Performance fluctuation }\end{array}$ \\
\hline $\begin{array}{l}\text { Duchon \& Drake } \\
(2009)\end{array}$ & $\begin{array}{l}\text { - Extreme love of self } \\
\text { - Grandiose sense of self- } \\
\text { importance } \\
\text { - Powerful sense of entitlement }\end{array}$ & - Ego defense mechanism & - Behave unethically \\
\hline $\begin{array}{l}\text { Aktas, Bodt, Bollaert, } \\
\text { \& Roll (2011) }\end{array}$ & $\begin{array}{l}\text { - Pervasive pattern of } \\
\text { grandiosity } \\
\text { - Need for admiration } \\
\text { - Lack of empathy }\end{array}$ & - CEO's personality trait & $\begin{array}{l}\text { - High bid in M\&A } \\
\text { premiums }\end{array}$ \\
\hline
\end{tabular}


The above discussion can be summarized by the following propositions:

Proposition 7: CEOs who have narcissism are more likely to be born with a trait of self-love and use the pronoun indicators of "I."

\subsection{Narcissism Cause and Consequence}

The dynamics of leaders has been studied for many years, and still, scholars are still looking into the cause and effect. One of the key traits that leaders have is the capability to reawaken emotions. de Vries and Miller (1985) discovered that followers are under the spell of leaders which will make them will feel proud, helpless, and dependent. Sometimes during this process of feeling dependent, followers over exceed their feelings and embrace the idea of an all-powerful leader, which the believer may think that this leader can fulfill their dependency needs (de Vries \& Miller, 1985). By this conception, a follower can destroy their analytical abilities.

Kernberg (1975) stated top leaders are usually prone to having narcissistic personalities of wanting extraordinary power and prestige for authority and leadership. Furthermore, certain types of narcissistic personalities have absolute self-confidence and certainty (Kohut, 2011). The various lists of narcissistic personality disorders are categorized as: excessive grandiosity, use of others, and showing off. Narcissist relies only on themselves and does not rely on others. Also, they believe to be independent but then again experience the feeling of emptiness. It is possible that to cover up their insecurity, they establish these kinds of factors of: authority, respect, and dominance. Furthermore, they expected others to accept their narcissistic characteristics of desires and wished to be catered to their needs (de Vries, 1985).

Kohut (2011) stated that there are three different narcissistic leaders, and it derives from reactive, self-deceptive, and constructive. The reactive narcissism is considered when there is a failure during the early childhood, and this can be represented by grandiose self and idealized parental image. The feelings of grand self-portrays describe a child who displays his or her capabilities to be admired. The construct of idealized parental image deals with a child who is perfect; they will be praised by the parents. This early success of interpersonal attachments can create a positive selfesteem. However, narcissistic can arise because parents behavior can be cold or uncaring, and does not give sufficient needs which arise the narcissist behavior of having a self-image of 'specialness' (de Vries, 1985). Therefore, reactive narcissists are cold, ruthless, grandiose, and exhibitionistic.

There is another type of narcissistic leaders who receive love from both parents and gets treated as a perfect person, and this is called self-deceptive narcissistic. Millard, Kohut, and Wolf (1979) describe this situation as over-stimulated or overburdened self. In the end, they have to follow their parent's footsteps and fulfill their parental hopes and dreams. Therefore, self-deceptive narcissists are milder, less tyrannical, want to be liked, however, lack empathy, and are obsessed with their needs. Lastly, effective narcissistic leaders are different compared to reactive and self-deceptive narcissistic leaders. Rather, they show signs of confidence about their personal worth. They have the patience to wait and to show talents when needed. Chatterjee and Hambrick (2007) discovered positive relationship in strategic dynamism and grandiosity for CEO with narcissism. It favored bold actions which resulted in extreme wins and extreme losses. Thus, there are different causes and consequences through various types of narcissistic leaders.

The above discussion can be summarized by the following propositions:

Proposition 8: CEOs who are born with narcissism trait are more likely to be in a state of self-preservation, independent, and exhibitionistic which may eventually lead to high-risk decisions to their self-interest because of extreme need for power, prestige, and grandiosity. 
Figure 3. Model of CEO Hubris as a Consequence

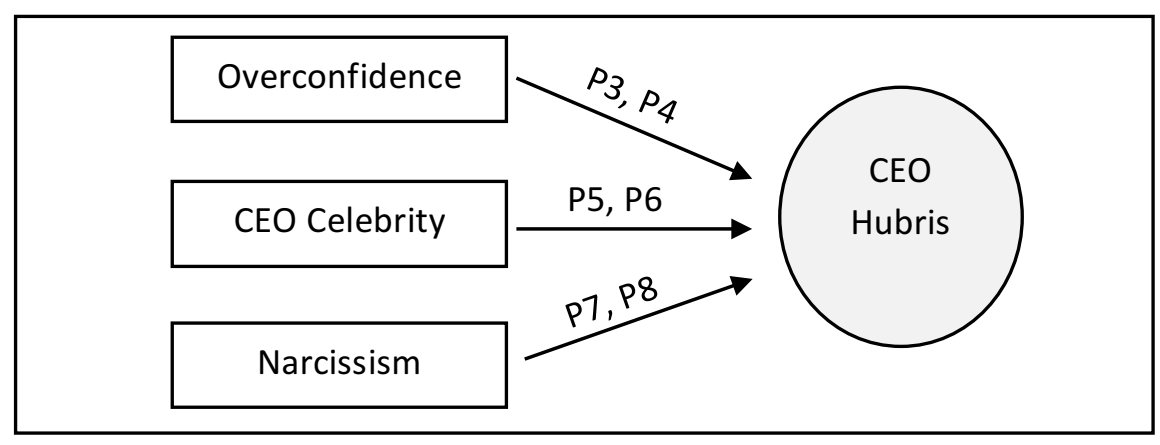

\section{DISCUSSION}

This review paper proposes a theoretical framework for understanding and clearing up the confusion of CEO hubris and the related constructs: overconfidence, CEO celebrity, and narcissism. This framework is significantly vital because it shows whether CEO hubris is an antecedent or consequence. The theory of CEO hubris can be considered as an antecedent when a CEO over-estimates by overly taking the extreme risk of a decision because of their characteristics of being arrogant and self-conceit (Roll, 1986). Also, the theory of CEO hubris can be considered as a consequence when antecedents of an overconfident CEO forms due to their initial success (Doukas \& Petmezas, 2007). Also, when a CEO who becomes a celebrity through mass media (Clapham and Schwenk, 1991). Lastly when a CEO with a high characteristic of narcissism of self-love (Hiller \& Hambrick, 2005, Duchon \& Drake, 2009) are initially involved. Thus, the analysis presented in this research have examined to clarify the confusion of CEO hubris being an antecedent or consequence. Also, it has attempted to clarify the related constructs which often use the word hubris interchangeably. The primary reason for the confusion is based on their similar outcomes and in using the word overconfidence and hubris interchangeably.

\section{LIMITATION AND FUTURE RESEARCH}

This review paper had examined existing research in the field of CEO hubris, overconfidence, CEO celebrity, and narcissism. It researched on finding the definition, causes, and consequences from these four related constructs. This research attempted to assess clear definitions and view of the four related constructs, however, precise and general definitions are still building, however, still scarce. The top scholars in each of the fields need to create a solid definition for future researchers for these areas. One of the primary confusion is because keywords and theories from these related constructs are still interchangeably used in current research from all four areas. Also, the construct measurement of analysis needs to be assembled more clearly between these four related constructs to reduce the confusion. One of the limitations of this paper is that the table for each study was mainly focused on the key papers. Therefore, the density of the table seems low.

A possible future research between CEO hubris and symbolic management will be interesting since there is a growing interest in these fields. Also, it will be interesting to empirically find out whether CEO hubris use symbolic actions for their success. Furthermore, it will be fascinating to research between CEO hubris and ownership structure in family business versus professional business. This research can bring an academic impact into the world of family business. Moreover, it would be interesting to do research on the positive aspects of CEO hubris, overconfidence, CEO celebrity and narcissism, since much of the current research shows negative consequences. We believe that during uncertainty and inertia, an overconfident CEOs can impact on company's initiative and possibly provide a positive outcome. Lastly, research on this area can further enhance the academic and practical knowledge of the individual and organizational level of judgments for business executives. 


\section{CONCLUSION}

This research paper assessed and reviewed the theory of CEO Hubris. Also, it examined the related constructs of overconfidence, CEO celebrity, and narcissism clearly. This literature review evaluated and offer propositions to future researchers who are interested in the field of CEO hubris. Research in these areas needs to be ongoing to help scholars and business practitioners to comprehend the process of hubris, overconfidence, CEO celebrity, and narcissism. It will contribute to help to determine how to avoid the pitfalls of the negative outcomes.

\section{ACKNOWLEDGMENT}

This work was supported by Incheon National University Research Grant in 2015.

\section{AUTHOR BIOGRAPHIES}

Hyunjun Park is an assistant professor in the field of strategic management/international business at Incheon National University. He holds B.S. in international studies from the University of California, Irvine and M.S. in business administration, and Ph.D. in the area of strategic management/international business from Seoul National University. His research has appeared in Journal of Small Business Innovation and Journal of Applied Business Research. His research interests include strategic innovation, corporate governance, CEO succession, and CSR.

Youngtae Yoo (contact author), is an assistant professor in the field of Tax and Accounting department at Incheon National University. He holds B.S. in mathematics, M.S., and Ph.D. in tax and accounting from Yonsei University. His research has appeared in Review of Pacific Basin Financial Markets and Poli, Korean Academic Society of business Administration, Korean Accounting Journal and Journal of Applied Business Research. His research interests include in financial accounting. E-mail: ytae@inu.ac.kr

\section{REFERENCES}

Aktas, N., De Bodt, E., Bollaert, H., \& Roll, R. (2012). CEO narcissism and the takeover process: From private initiation to deal completion. From private initiation to deal completion.

Alpert, M., \& Raiffa, H. (1982). A progress report on the training of probability assessors.

Barber, B. M., \& Odean, T. (2001). Boys will be boys: Gender, overconfidence, and common stock investment. Quarterly Journal of Economics, 261-292.

Barber, B., \& Odean, T. (1999). Do investors trade too much? American Economic Review, 89(5), 262.

Baum, J.A., \& Powell, W. W. (1995). Cultivating an institutional ecology of organizations: Comment on Hannan, Carroll, Dundon, and Torres. American sociological review, 60(4), 529-538.

Ben-David, I., Graham, J. R., \& Harvey, C. R. (2007). Managerial overconfidence and corporate policies (No. w13711). National Bureau of Economic Research.

Blascovich, J., Ginsburg, G. P., \& Howe, R. C. (1975). Blackjack and the risky shift, II: Monetary stakes. Journal of Experimental Social Psychology, 11(3), 224-232.

Bogart, L. M., Benotsch, E. G., \& Pavlovic, J. D. P. (2004). Feeling superior but threatened: The relation of narcissism to social comparison. Basic and Applied Social Psychology, 26(1), 35-44.

Brown, R., \& Sarma, N. (2007). CEO overconfidence, CEO dominance and corporate acquisitions. Journal of Economics and Business, 59(5), 358-379.

Camerer, C., \& Lovallo, D. (1999). Overconfidence and excess entry: An experimental approach. The American Economic Review, 89(1), 306-318.

Campbell, W. K., Goodie, A. S., \& Foster, J. D. (2004). Narcissism, confidence, and risk attitude. Journal of Behavioral Decision Making, 17(4), 297-311.

Campbell, W. K., Reeder, G. D., Sedikides, C., \& Elliot, A. J. (2000). Narcissism and comparative self-enhancement strategies. Journal of Research in Personality, 34(3), 329-347.

Campbell, W. K., Rudich, E. A., \& Sedikides, C. (2002). Narcissism, self-esteem, and the positivity of self-views: Two portraits of self-love. Personality and Social Psychology Bulletin, 28(3), 358-368.

Chatterjee, A., \& Hambrick, D. C. (2007). It's all about me: Narcissistic chief executive officers and their effects on company strategy and performance. Administrative Science Quarterly, 52(3), 351-386. 
Chen, C. C., \& Meindl, J. R. (1991). The construction of leadership images in the popular press: The case of Donald Burr and People Express. Administrative Science Quarterly, 521-551.

Clapham, S. E., \& Schwenk, C. R. (1991). Self-serving attributions, managerial cognition, and company performance. Strategic Management Journal, 12(3), 219-229.

Dalton, G. W., Barnes, L. B., \& Zaleznik, A. (1968). The distribution of authority in formal organizations. Harvard University, Division of Research, Graduate School of Business Administration.

De Bondt, W. F., \& Thaler, R. H. (1995). Financial decision-making in markets and firms: A behavioral perspective. Handbooks in operations research and management science, 9, 385-410.

de Vries, Kets. (1994). The leadership mystique. The Academy of Management Executive, 8(3), 73-89.

de Vries, M. F. R. Kets., \& Miller, D. (1985). Narcissism and leadership: An object relations perspective. Human Relations, $38(6), 583-601$.

Deephouse, D. L. (2000). Media reputation as a strategic resource: An integration of mass communication and resource-based theories. Journal of Management, 26(6), 1091-1112.

Deluga, R. J. (1997). Relationship among American presidential charismatic leadership, narcissism, and rated performance. The Leadership Quarterly, 8(1), 49-65.

Dickinson, K. A., \& Pincus, A. L. (2003). Interpersonal analysis of grandiose and vulnerable narcissism. Journal of Personality Disorders, 17(3), 188-207.

Doukas, J. A., \& Petmezas, D. (2007). Acquisitions, Overconfident Managers and Self-attribution Bias. European Financial Management, 13(3), 531-577.

Duchon, D., \& Drake, B. (2009). Organizational narcissism and virtuous behavior. Journal of Business Ethics, 85(3), 301-308.

Ellis, H. (1898). Auto-Erotism. Alienist and Neurologist.

Emmons, R. A. (1984). Factor analysis and construct validity of the narcissistic personality inventory. Journal of Personality Assessment, 48(3), 291-300.

Fischhoff, B., \& Beyth, R. (1975). I knew it would happen: Remembered probabilities of once-future things. Organizational Behavior and Human Performance, 13(1), 1-16.

Fombrun, C. (1996). Reputation. John Wiley \& Sons, Ltd.

Freud, S. (2014). On narcissism: An introduction. Read Books Ltd.

Gist, M. E., \& Mitchell, T. R. (1992). Self-efficacy: A theoretical analysis of its determinants and malleability. Academy of Management Review, 17(2), 183-211.

Graffin, S. D., Wade, J. B., Porac, J. F., \& McNamee, R. C. (2008). The impact of CEO status diffusion on the economic outcomes of other senior managers. Organization Science, 19(3), 457-474.

Griffin, D., \& Tversky, A. (1992). The weighing of evidence and the determinants of confidence. Cognitive Psychology, 24(3), 411-435.

Hambrick, D. C., \& Mason, P. A. (1984). Upper echelons: The organization as a reflection of its top managers. Academy of Management Review, 9(2), 193-206.

Harter, S. (1990). Causes, correlates, and the functional role of global self-worth: A life-span perspective.

Haspeslagh, P. C., \& Jemison, D. B. (1991). Managing acquisitions: Creating value through corporate renewal (Vol. 416). New York: Free Press.

Hayward, M. (2007). Ego check: Why executive hubris is wrecking companies and careers and how to avoid the trap (pp. 1-251). Kaplan.

Hayward, M. L., \& Hambrick, D. C. (1997). Explaining the premiums paid for large acquisitions: Evidence of CEO hubris. Administrative Science Quarterly, 103-127.

Hayward, M. L., Rindova, V. P., \& Pollock, T. G. (2004). Believing one's own press: The causes and consequences of CEO celebrity. Strategic Management Journal, 25(7), 637-653.

Hayward, M. L., Shepherd, D. A., \& Griffin, D. (2006). A hubris theory of entrepreneurship. Management Science, 52(2), 160172.

Hiller, N. J., \& Hambrick, D. C. (2005). Conceptualizing executive hubris: the role of (hyper-) core self-evaluations in strategic decision-making. Strategic Management Journal, 26(4), 297-319.

John, O. P., \& Robins, R. W. (1994). Accuracy and bias in self-perception: individual differences in self-enhancement and the role of narcissism. Journal of Personality and Social Psychology, 66(1), 206.

Judge, T. A., LePine, J. A., \& Rich, B. L. (2006). Loving yourself abundantly: relationship of the narcissistic personality to selfand other perceptions of workplace deviance, leadership, and task and contextual performance. Journal of Applied Psychology, 91(4), 762.

Katz, E. (1980). On conceptualizing media effects. Studies in communication, 1, 119-141.

Kernberg, O. F. Borderline conditions and pathological Narcism, New York (Jason Aronson) 1975.

Kohut, H. (2011). The Search for the Self: Selected Writings of Heinz Kohut 1978-1981. Karnac Books.

Kroll, M. J., Toombs, L. A., \& Wright, P. (2000). Napoleon's tragic march home from Moscow: Lessons in hubris. The Academy of Management Executive, 14(1), 117-128.

Lasch, C. (1991). The culture of narcissism: American life in an age of diminishing expectations. WW Norton \& Company.

Copyright by author(s); $\underline{\mathrm{CC}-\mathrm{BY}}$ 
Li, J., \& Tang, Y. I. (2010). CEO hubris and firm risk taking in China: The moderating role of managerial discretion. Academy of Management Journal, 53(1), 45-68.

Lin, B. X., Michayluk, D., Oppenheimer, H. R., \& Reid, S. F. (2008). Hubris amongst Japanese bidders. Pacific-Basin Finance Journal, 16(1), 121-159.

Lubit, R. (2002). The long-term organizational impact of destructively narcissistic managers. The Academy of Management Executive, 16(1), 127-138.

Malmendier, U., \& Tate, G. (2005). CEO overconfidence and corporate investment. The Journal of Finance, 60(6), 2661-2700.

Malmendier, U., \& Tate, G. (2008a). Who makes acquisitions? CEO overconfidence and the market's reaction. Journal of Financial Economics, 89(1), 20-43.

Malmendier, U., \& Tate, G. (2008b). Superstar CEOs (No. w14140). National Bureau of Economic Research.

Malmendier, U., Tate, G., \& Yan, J. (2007). Corporate financial policies with overconfident managers (No. w13570). National Bureau of Economic Research.

Meadows, D. H., Meadows, D. L., Randers, J., \& Behrens, W. W. (1972). The limits to growth. New York, 102.

Millard, D., Kohut, H., \& Wolf, E. S. (1979). 'The Disorders of the Self and their Treatment: An Outline', International Journal of Psycho-Analysis, 59.

Morf, C. C., \& Rhodewalt, F. (2001). Unraveling the paradoxes of narcissism: A dynamic self-regulatory processing model. Psychological Inquiry, 12(4), 177-196.

Neale, M. A., \& Bazerman, M. H. (1983). The role of perspective-taking ability in negotiating under different forms of arbitration. Industrial \& Labor Relations Review, 36(3), 378-388.

Pollock, T. G., \& Rindova, V. P. (2003). Media legitimation effects in the market for initial public offerings. Academy of Management Journal, 46(5), 631-642.

Raj, M., \& Forsyth, M. (2003). Hubris amongst UK bidders and losses to shareholders. International Journal of Business, 8(1), 116.

Raskin, R. N., \& Hall, C. S. (1979). A narcissistic personality inventory. Psychological reports.

Raskin, R., \& Shaw, R. (1988). Narcissism and the use of personal pronouns. Journal of Personality, 56(2), 393-404.

Raskin, R., \& Terry, H. (1988). A principal-components analysis of the Narcissistic Personality Inventory and further evidence of its construct validity. Journal of Personality and Social Psychology, 54(5), 890-902.

Regan, J. W., Gosselink, H., Hubsch, J., \& Ulsh, E. (1975). Do people have inflated views of their own ability? Journal of Personality and Social Psychology, 31(2), 295-301.

Roll, R. (1986). The hubris hypothesis of corporate takeovers. Journal of business, 197-216.

Rotter, J. B. (1954). Social learning and clinical psychology.

Russo, J. E., \& Schoemaker, P. J. (1992). Managing overconfidence. Sloan Management Review, 33(2), 1-11.

Sanford, F. H. (1942). Speech and personality. Psychological Bulletin, 39(10), 811.

Seth, A., Song, K. P., \& Pettit, R. (2000). Synergy, managerialism or hubris? An empirical examination of motives for foreign acquisitions of US firms. Journal of International Business Studies, 31(3), 387-405.

Simon, M., \& Houghton, S. M. (2003). The relationship between overconfidence and the introduction of risky products: Evidence from a field study. Academy of Management Journal, 46(2), 139-149.

Taylor, S. E., \& Brown, J. D. (1988). Illusion and well-being: a social psychological perspective on mental health. Psychological Bulletin, 103(2), 193-210.

Wade, J. B., Porac, J. F., Pollock, T. G., \& Graffin, S. D. (2006). The burden of celebrity: The impact of CEO certification contests on CEO pay and performance. Academy of Management Journal, 49(4), 643-660.

Wallace, H. M., \& Baumeister, R. F. (2002). The performance of narcissists rises and falls with perceived opportunity for glory. Journal of Personality and Social Psychology, 82(5), 819-834.

Young, S. M., \& Pinsky, D. (2006). Narcissism and celebrity. Journal of Research in Personality, 40(5), 463-471. 